\title{
EVALUAREA A PATRU TESTE FENOTIPICE PENTRU DETECTAREA CARBAPENEMAZELOR DE TIP OXA-48 LA ENTEROBACTERIACEAE
}

\author{
Daniela Tălăpan ${ }^{1,2}$, Olga Mihaela Dorobăț ${ }^{1}$, Coralia Bleotu $^{3}$, Ioana Aldea ${ }^{3}$, \\ Laura Necula ${ }^{3}$, Dragoş Florea ${ }^{1,2}$, Gabriel Adrian Popescu ${ }^{1,2}$, \\ Adrian Streinu-Cercel ${ }^{1,2}$, Alexandru Rafila ${ }^{1,2}$

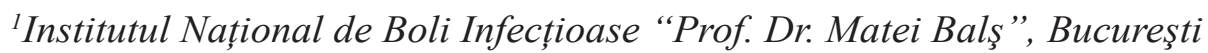 \\ ${ }^{2}$ Universitatea de Medicină și Farmacie "Carol Davila”, Bucureşti \\ ${ }^{3}$ Institutul de Virusologie Ștefan S. Nicolau, Romanian Academy, Bucureşti
}

\begin{abstract}
REZUMAT
Enterobacteriaceaele producătoare de carbapenemază au potenţialul de a se răspândi rapid in spitale şi în instituţiile de îngrijire a persoanelor cu dizabilităţi, devenind o problemă majoră de sănătate publică şi pentru controlul infecţiilor. PCR rămâne metoda de referinţă pentru identificarea acestor tulpini, dar este încă scumpă. În acest studiu am evaluat performanţa a patru teste fenotipice pentru identificarea Enterobacteriaceaelor producătoare de carbapenemază tip OXA-48 (Oxacilinază-48). Aceste teste au fost: testul Hodge modificat (MHT), un test care conţine discuri cu meropenem singur sau în combinaţie cu diferiţi inhibitori şi temocilina, un test enzimatic şi unul imunocromatografic. Testele s-au efectuat şi interpretat conform ghidurilor sau recomandărilor producătorilor. Cel mai frecvent microorganism inclus în studiu a fost Klebsiella pneumoniae. Cu o singură excepție (MHT 87,5\%), toate testele au avut o specificitate de $100 \%$. Sensibilitatea a fost de 91,25\% pentru MHT, $90 \%$ pentru combinaţia de discuri, $95 \%$ pentru testul enzimatic şi $82,5 \%$ pentru testul imunocromatografic.
\end{abstract}

Cuvinte cheie: Enterobacteriaceae, carbapenemază OXA-48, teste fenotipice

\section{INTRODUCERE}

Rezistența la carbapeneme poate fi dobândită prin impermeabilitate plus hiperproducție de AmpC sau prin producerea de carbapenemază, enzimă care hidrolizează carbapenemele. Există 3 clase de carbapenemaze importante clinic, conform sistemului de clasificare moleculară al lui Ambler: A, B și D. Clasa D de carbapenemaze cuprinde beta-lactamazele de tip OXA-48 codificate plasmidic, fapt care crește riscul de a se răspândi de la un microorganism la altul și în spitale (1).

După prima izolare a carbapenemazei OXA48 în Turcia în 2001 la o tulpină de Klebsiella pneumoniae (2), acest tip s-a răspândit în toată
Europa (3-7), Orientul Mijlociu (8-10) și America de Nord (11).

Scopul prezentului studiu a fost de a evalua patru teste fenotipice pentru detectarea carbapenemazelor de tip OXA-48 la Enterobacteriaceae. PCR rămâne metoda de referință pentru aceasta, însă este scumpă și necesită personal specializat.

\section{MATERIALE ŞI METODE}

În perioada octombrie 2013 - iulie 2015, în Institutul Naţional de Boli Infecțioase „Prof. Dr. Matei Balș“ au fost izolate, de la pacienți și purtători, tulpini de Enterobacteriaceae cu sensibilitate diminuată la unul sau mai multe carbapeneme 
conform ghidului EUCAST (European Committee on Antimicrobial Susceptibility Testing). Identificarea și testarea sensibilității la antibiotice a acestor tulpini s-a realizat cu ajutorul panelurilor de Gram negativi Combo 56 la MicroScan Walk Away (Siemens, USA). Pentru acest studiu au fost selectate 112 tulpini non-duplicat de Enterobacteriaceae, bine caracterizate $\mathrm{cu}$ ajutorul testelor moleculare (PCR): 80 de tulpini pozitive pentru gena $b l a_{\text {OXA-48 }}$ și 32 de tulpini neproducătoare de carbapenemază.

Testele fenotipice studiate au fost MHT (recomandat de ghidul CLSI (Clinical and Laboratory Standards Institute), KPC (Klebsiella pneumoniae carbapenemază), MBL (Metallo-beta-lactamază) și OXA-48 Confirm kit (Rosco Diagnostica, Denmark), Rapidec ${ }^{\circledR}$ Carba NP (bioMerieux, France) (ambele recomandate de EUCAST) și OXA-48 $K$-SeT (Coris BioConcept, Belgium).

\section{MHT}

Testul Hodge modificat s-a efectuat și interpretat conform ghidului CLSI, utilizând tulpina Klebsiella pneumoniae ATCC BAA 1705 ca martor pozitiv (12).

Pe agar Mueller Hinton E (MHE, bioMerieux, France) s-a însămânțat o suspensie de 1/10 din concentrația 0,5 McFarland a tulpinii E. coli ATCC 25922. Ulterior, s-a adăugat un disc de ertapenem de $10 \mu \mathrm{g}$ în centrul plăcii și tulpinile bacteriene de cercetat s-au însămânțat sub formă de linie dreaptă începând de la antibiotic până la marginea plăcii. Citirea s-a realizat după incubare la $35^{\circ} \mathrm{C}$ timp de $18-20$ ore și distorsionarea zonei de inhibiție a creșterii bacteriene în jurul discului cu ertapenem la oricare dintre tulpini și la tulpina martor s-a citit ca test pozitiv pentru producerea de carbapenemază.

\section{KPC, MBL and OXA-48 Confirm kit}

Această trusă conține meropenem $(10 \mu \mathrm{g})$ singur sau în combinație cu diferiți inhibitori de beta-lactamază: meropenem $(10 \mu \mathrm{g})$ plus acid phenilboronic (KPC and $\mathrm{AmpC}$ ), meropenem
$(10 \mu \mathrm{g})$ plus acid dipicolinic (MBL), meropenem $(10 \mu \mathrm{g})$ plus cloxacilină $(\mathrm{AmpC})$ și Temocilină $(30 \mu \mathrm{g})$.

Testul s-a realizat și interpretat conform recomandărilor producătorului. Pe un mediu MHE $\mathrm{s}$-a inoculat o concentrație de 0,5 McFarland din tulpina de cercetat, apoi s-au așezat tabletele la distanță egală una de cealaltă. Plăcile au fost incubate la $35^{\circ} \mathrm{C}$ timp de $18-20$ de ore și au fost citite prin măsurarea diametrului zonei de inhibiție a creșterii bacteriene în jurul fiecărei tablete, în milimetri. Lipsa unei astfel de zone în jurul tabletei care conține temocilină este indicatoare pentru producerea de carbapenemază de tip OXA-48.

\section{Rapidec ${ }^{\circ}$ Carba NP}

Acesta este un test enzimatic cu modificarea pH-ului mediului în care se găsesc tulpinile producătoare de carbapenemază. Trusa conține imipenem (ca substrat pentru carbapenemază), roșu fenol (ca indicator de pH) și zinc (pentru înlesnirea detecției de MBL). Pentru realizarea testului, se folosește tulpină bacteriană proaspătă (18-24 de ore) însămânțată pe mediul geloză sânge (s-a folosit COLS - agar Columbia cu sânge de berbec de la Oxoid, UK) sau pe MHE. Rezultatele testului au fost citite după 30 de minute sau după încă o oră și jumătate de incubare la $37^{\circ} \mathrm{C}$. Modificarea culorii din roșu (control negativ) în galben, portocaliu-galben sau portocaliu-roșcat în godeul test a fost indicatoare pentru producerea de carbapenemază de orice tip.

\section{OXA-48 K-SeT}

Acest test a apărut pe piață în 2015 și se bazează pe tehnologia cu membrană care conține nanoparticule de aur coloidal conjugate cu un anticorp monoclonal direcționat împotriva unui epitop al carbapenemazei de tip OXA-48 și un alt anticorp monoclonal direcționat către un alt epitop al carbapenemazei de tip OXA-48, atașat de o membrană de nitroceluloză. 
Testul poate detecta carbapenemazele de tip OXA-48 utilizând o singură colonie a tulpinii de Enterobacteriaceae crescută pe un mediu cu agar. Trusa conține un substrat care lizează bacteria și casete de reacție ambalate individual. După ce colonia bacteriană se suspensionează în soluția de liză, se pun 3 picături în godeul pentru probă și se citește după 15 minute.

Performanța testelor fenotipice pentru detectarea producătorilor de carbapenemază s-a determinat utilizând metoda genotipică ca standard. Sensibilitatea unui test fenotipic a fost calculat utilizând numărul de izolate care au dat rezultate adevărat-pozitive, iar specificitatea s-a calculat utilizând numărul de izolate care au dat rezultate adevărat-negative.

\section{REZULTATE}

Tulpinile bacteriene incluse în acest studiu au fost aproximativ în mod egal izolate de la femei $(n=53)$ și de la bărbați $(n=59)$. Majoritatea tulpinilor $(78,57 \%)$ au fost izolate de la persoane cu vârsta egală sau mai mare de 51 de ani.

Tulpinile au provenit de la pacienți și de la purtători (Tabelul 1). Dintre tulpinile izolate de la pacienți, $75 \%$ au fost producătoare de carbapenemază, iar de la purtători doar 55\%. Toate tulpinile izolate de la nivelul tractului respirator inferior au fost pozitive pentru gena $b l a_{\text {OXA-48 }}$ și 5 din 6 tulpini izolate din sânge. Un procent de 74,6 dintre tulpinile izolate din urină au fost producătoare de carbapenemază OXA-48.

TABELUL 1. Tulpinile izolate

\begin{tabular}{|l|c|c|c|}
\hline $\begin{array}{l}\text { Prelevate } \\
\text { clinice }\end{array}$ & Carba pozitiv & Carba negativ & Total \\
\hline Urină & 47 & 16 & 63 \\
\hline Spută & 9 & 0 & 9 \\
\hline Lichid pleural & 1 & 0 & 1 \\
\hline Plăgi & 7 & 5 & 12 \\
\hline Sânge & 5 & 1 & 6 \\
\hline $\begin{array}{l}\text { Lichid de } \\
\text { sonificare }\end{array}$ & 0 & 1 & 1 \\
\hline Tampon rectal & 11 & 9 & 20 \\
\hline
\end{tabular}

Tulpinile bacteriene izolate au fost următoarele: Klebsiella pneumoniae $(\mathrm{n}=95)$, E. coli $(\mathrm{n}=6)$,
Enterobacter cloacae $(\mathrm{n}=5)$, Enterobacter aerogenes $(\mathrm{n}=1),(\mathrm{n}=4)$ și Morganella morgannii $(\mathrm{n}=1)$. Dintre tulpinile de Klebsiella pneumoniae, 74,73\% au fost producătoare de carbapenemază OXA-48; nici o tulpină de Enterobacter cloacae și Morganella morgannii nu a fost producătoare de carbapenemază. Tulpina de Enterobacter aerogenes inclusă în studiu a fost pozitivă pentru OXA-48.

După efectuarea MHT, 7 din 80 de tulpini au dat rezultate fals negative și 4 din 32 - fals pozitive. Utilizând combinația de tablete de la Rosco Diagnostica, s-a ratat identificarea a 8 din cele 80 de tulpini OXA-48 pozitive, dar au fost identificate corect toate tulpinile neproducătoare de carbapenemază. Testul enzimatic a avut 4 rezultate fals negative iar cel imunocromatografic 14 , ambele teste identificând corect tulpinile neproducătoare de carbapenemază.

Sensibilitatea și specificitatea fiecărui test fenotipic este prezentată în Tabelul 2.

TABELUL 2. Sensibilitatea şi specificitatea testelor fenotipice

\begin{tabular}{|l|c|c|c|c|c|}
\hline Rezultat & $\begin{array}{c}\text { PCR } \\
\text { blaOXA-48 }\end{array}$ & MHT & $\begin{array}{c}\text { KPC, MBL } \\
\text { and } \\
\text { OXA-48 }\end{array}$ & $\begin{array}{c}\text { Rapidec } \\
\text { CarbaNP }\end{array}$ & $\begin{array}{c}\text { OXA-48 } \\
\text { K-SeT }\end{array}$ \\
\hline Pozitiv (nr.) & 80 & 73 & 72 & 76 & 66 \\
\hline Negativ (nr.) & 32 & 28 & 32 & 32 & 32 \\
\hline Sensibilitate (\%) & & 91,25 & 90 & 95 & 82.5 \\
\hline Specificitate (\%) & & 87,5 & 100 & 100 & 100 \\
\hline
\end{tabular}

\section{DISCUŢII}

Așa cum este citat și în literatură, tulpinile rezistente sau intermediare la carbapeneme au fost izolate de la pacienți de vârstă înaintată, care cel mai probabil au avut tratament cu antibiotice de-a lungul vieții. Peste trei sferturi dintre aceștia au avut peste 50 de ani.

Majoritatea tulpinilor din studiul nostru care au prezentat sensibilitate diminuată la unul sau mai multe carbapeneme au fost Klebsiella pneumoniae, în concordanță cu datele din literatură $(13,14)$.

Dintre testele incluse în studiu, MHT nu este recomandat de ghidurile EUCAST, din cauza sensibilităţii și specificității reduse. Rezultatele 
acestui studiu au arătat ca MHT are cea mai mică specificitate dintre testele fenotipice studiate, dar o sensibilitate bună $(91,25 \%)$ în detectarea tulpinilor producătoare de $\mathrm{OXA}-48$, rezultat apropiat de cele din literatură: $100 \%$ sensibilitate în studiul lui Girlich D (15), 94\% la Bartolini A (14) și 93\% la Doyle D (16).

Trusa KPC, MBL and OXA-48 Confirm kit a avut $100 \%$ specificitate și $90 \%$ sensibilitate în detectarea tulpinilor pozitive pentru OXA-48 în acest studiu. Specificitatea testului a fost la fel ca in studiul lui van Dijk (100\%), dar sensibilitatea mai mică (90\% versus 100\%) (17).

Rapidec CarbaNP a avut o specificitate de $100 \%$, ca în studiul lui Dortet L, dar sensibilitatea mai mică (95\% versus 99\%) (18). Într-un studiu de Kabir MH, sensibilitatea a fost 97,8\% și specificitatea 98,56\% (19).

Cel mai nou test fenotipic pentru detectarea carbapenemazelor de tip OXA-48 la Enterobacteriaceae introdus pe piață este OXA-48 K-SeT. Deși rezultatele din literatură precizează o sensibilitate și o specificitate de $100 \%(20,21)$, rezultatele acestui studiu pentru acest test arată o sensibilitate mai mică $(82,5 \%)$, poate datorată și limitei de detecție $(0,125 \mathrm{ng} / \mathrm{ml})$, fiind cunoscut faptul că tulpinile tip OXA-48 sunt slab producătoare de carbapenemază.

\section{CONCLUZII}

Dintre testele fenotipice $\mathrm{cu}$ specificitate $100 \%$, Rapidec CarbaNP a avut cea mai mare sensibilitate în detectarea tulpinilor producătoare de carbapenemază OXA-48. Acesta este de asemenea un test al cărui rezultat este gata în 2-4 ore, fiind foarte util în identificarea rapidă a acestui tip de microorganisme și în demararea imediată a măsurilor de control al infecțiilor, cu scopul de a limita răspândirea unor astfel de tulpini in spitale și alte instituţii de îngrijire a bolnavilor.

KPC, MBL and OXA-48 Confirm kit are, de asemenea, o bună sensibilitate pentru detectarea tulpinilor producătoare de carbapenemaze tip-OXA-48, însă rezultatul este disponibil după 18-20 de ore.

În pofida specificității reduse, MHT rămâne util datorită ușurinței de realizare și a sensibilității bune pentru detectarea tulpinilor producătoare de carbapenemaze de tip OXA-48.

OXA-48 $\mathrm{K}$-SeT este un test rapid și specific, dar în studiul acesta a arătat o sensibilitate mică.

Mulțumiri: Această lucrare a fost susținută de Programul Operațional Sectorial pentru Dezvoltarea Resurselor Umane (SOP HRD), finanțat prin Fondul Social European și Guvernul României cu contractul numărul POSDRU/159/ 1.5/S/137390/. 